\title{
ANALISIS KEMAMPUAN DESAIN PEMBELAJARAN GURU NON-LINIER DI PAUD/TK SE-KOTA BIMA
}

\author{
Lukman $\mathcal{E}$ Muslim $^{1}$ \\ Pengajar pada Institut Agama Islam Muhammadiyah Bima \\ putrasanggar231@gmail.com
}

\section{ABSTRAK}

Penelitian ini berjudul: "Analisis kemampuan desain pembelajaran guru non- linier di PUAD/TK Se-Kota Bima". Tujuan adalah untuk mengalisis dan melihat bagaimana kemampuan guru non-linier dalam mendesain pembelajaran di dalam kelas maupun di luar kelas, terutama di PAUD/ TK yang ada di kota Bima.

Metode penelitian yakni kualitatif dengan Jenis penelitian field research, yaitu peneliti mengadakan penelitian langsung terhadap objek yang diteliti dan dilakukan pengumpulan data yang ditemukan di lapangan. Teknik pengumpulan data dilakukan dengan pengamatan partisipasi pasif, melalui observasi, wawancara dan dokumentasi, serta triangulasi.

Temuan penelitian: pertama, pada saat proses pembelajaran berlangsung guru biasanya diawali dengan kegiatan seperti berdo'a sebelum belajar, kemudian mendengarkan acarahan dari guru dan meperhatikan apa yang gurunya perintah. Selain itu, guru menyiapkan membuat perangkat pembelajaran seperti; Protap (Program Tahunan), Promes (Program Semester), Modul, RPKH, RPKM, dan silabus, Protap adalah program pengajaran satu tahun, yang berisi inti dari program pembelajaran yang kemudian dijabarkan dalam promes. Dan kurikulum berdasarkan tematema pada Kelompok A dan Kelompok B, mempelajari ciri-ciri rumusan tujuan dari enam aspek yakni: 1) Nilai Agama dan Moraal, 2) Kognitif, 3) Motorik, 4) Sosial emosional, 5) Bahasa, dan 6) Seni.

Kedua, Kekurangan-kekurangan yang dilakukan oleh guru-guru PAUD/ RA non-linier menjadi penyebab terhambatnya kreativitas dalam mendesain di dalam kelas, yakni tidak bisa membuat silabus, RPKH, RPKM, serta membuat Alat Permainan Edukatif (APE) sesuai dengan

${ }^{1}$ Lukman. M.Pd, dkk. Staf Pengajar pada Institut Agama Islam Islam Muhammadiyah Bima 
tema-tema yang diajarkan pada semester I dan Semester 2. Dan Diantara hambatan lain juga ialah, Tipe kepemimpinan guru yang otoriter, Gaya guru yang monoton dalam mengajar, Kepribadian guru yang kurang baik, Pengetahuan guru. Dan ketiga, Keberhasilan belajar sangat ditentukan oleh tenaga pengajarnya. Lalu mendesain pembelajaran guru juga perlu membentuk berkepribadian anak seperti sifat jujur, disiplin, tanggung jawab, toleransi, gotong royong, santun, percaya diri, wibawa, dan lainlain.

Kata Kunci: Kemampuan Desain Pembelajaran, Guru, dan PAUD/TK.

\section{PENDAHULUAN}

Guru merupakan salah satu profesi yang berperan dalam membentuk dan menentukan kualitas Sumber Daya Manusia (SDM) di masa yang akan datang. Oleh sebab itu, untuk mendapatkan Sumber Daya Manusia (SDM) berkualitas di masa yang akan datang, maka diperlukan guru yang berkualitas pula. Salah satu cara untuk meningkatkan kualitas guru adalah dengan meningkatkan kompetensi pedagogiknya. Kompetensi merupakan kemampuan yang dibutuhkan untuk dapat berkinerja unggul. Kompetensi lebih dari sekedar pengetahuan dan keterampilan (skill). Kompetensi juga melibatkan kemampuan untuk memenuhi tuntutan yang kompleks dengan menggambarkan dan memobilisasi sember daya psikososial (skill dan attitudes) dalam konteks tertentu.

Dalam Undang-Undang Republik Indonesia Nomor 14 Tahun 2005 Tentang Guru dan Dosen disebutkan bahwa "Guru wajib memiliki kualifikasi akademik, kompetensi, sertifikat pendidik, sehat jasmani dan rohani, serta memiliki kemampuan untuk mewujudkan tujuan pendidikan nasional" ${ }^{2}$ Kompetensi yang harus dimiliki oleh guru dijelaskan secara lebih detail dalam Peraturan menteri pendidikan Nasional Republik Indonesia Nomor 16 Tahun 2007 tentang standar kualifikasi akademik dan kompetensi guru. Dalam peraturan tersebut disebutkan bahwa ada 4 kompetensi utama yang harus dimiliki oleh Guru, yaitu kompetensi pedagogik, kompetensi kepribadian, kompetensi sosial dan kompetensi profesional. ${ }^{3}$ Keempat kompetensi tersebut terintegrasi dalam kinerja guru.

${ }^{2}$ Undang-Undang Nomor 14 tahun 2005 Tentang Guru Dan Dosen, 56.

${ }^{3} \mathrm{Ibid}, \ldots . .59$.

Jurnal Pelang̉i Jurnal pemikiran dan penelitian pendidkan Islam anak Usia Dini 
Polemik tentang guru tidak boleh naik pangkat jika mengajarnya tidak sesuai dengan ijazah yang dimiliki terjawab sudah. Dirjen GTK PAUD dan Dikmas telah memastikan bahwa guru yang bersertifikat pendidik yang diangkat sampai tahun 2015, dapat mengajukan kenaikan pangkat sesuai dengan pangkat tertinggi di dalam jenjang kepangkatan guru sepanjang mengajar sesuai dengan bidang/mata pelajaran pada sertifikat pendidiknya walaupun tidak linier dengan kualifikasi akademiknya. ${ }^{4}$

Banyak guru yang mengajar tidak sesuai dengan bidang studi yang diampuh di sekolah, masalah inilah yang banyak ditemukan pada guru. Pada sisi yang lain, posisi guru non-linier di PUAD/TKjuga dihadapkan dengan tanggungjawab profesional dalam melaksanakan desain kegiatan pembelajaran bagi peserta didiknya di tingkat satuan pendidikan. Hanya saja yang menjadi permasalahanya bahwa secara akademik para guru non-linier masih belum maksimal melaksanakan desain pembelajaran, dikerenakan minimnya kemampuan akademis yang berkaitan dengan dasar keilmuan yang dimiliki oleh para guru non-linier di PUAD/TK. Sehingga cenderung kegiatan pembelajaran yang dilaksanakan para guru dinilai monoton dan terkesan hanya menyelesaikan tugas mengajar semata. ${ }^{5}$

Belum permasalahan yang dihadapi oleh para guru non-linier dari sisi adminstarasi bertentangan dengan standar kualifikasi yang dipersyaratan Undang-Undang No.14/Tahun 2005 tentang guru dan dosen Pasal 1 Butir (9) yang menegaskan bahwa "kualifikasi akademik adalah ijazah jenjang pendidikan akademik yang harus dimiliki oleh para guru atau dosen sesuai dengan jenis, jenjang, dan satuan pendidikan formal di tempat penugasan. ${ }^{6}$

Tujuan dari kemampuan desain pembelajaran guru non-Linier di Pendidikan Anak Usia Dini (PAUD), diharapkan bagi guru-guru nonlinier dapat membuat serta mendesain kegiatan pembelajaran seperti: membuat silabus, RPKH, RPKM, serta membuat Alat Permainan

${ }^{4}$ Roby Maulana Putra, Hubungan antara Kemampuan Mengajar Guru TIK Non-Liner dengan Hasil Belajar Siswa pada Mata Pelajaran Teknologi Informasi dan Komunikasi (TIK), 8.

${ }^{5}$ Sulis Triyono, dkk., Tentang Penguatan Kompetensi Pedagogik Mahasiswa Jurusan Pendidikan Bahasa Jerman FBS Universitas Negeri Yogyakarta, 12.

${ }^{6}$ Umar, Pengantar Profesi Keguruan, (Jakarta: PT. Rajagrafindo Persada: Cetakan ke-1 januari 2019), 19. 
Edukatif (APE) sesuai dengan tema-tema yang diajarkan pada semester I dan Semester 2 jika tidak tersedia di sekolah Taman Kanak-Kanak dan PAUD tersebut.

Desain pembelajaran yang dilakukan oleh guru no-linier sebagai observasi awal di beberapa Taman Kanak-Kanak di Kota Bima, seperti Taman Kanak-Kanak Aisyiyah I Kota Bima, Taman Kanak-Kanak Aisyiyah II Kota Bima, Taman Kanak-Kanak Aisyiyah II Kota Bima, kalau proses kegiatan pembelajaran yang telah dilakukan oleh guru-guru non-linier belum dilakukan hanya mereka datang megajar sesuai yang dilakukan oleh guru-guru seniornya, atau tidak melakukan dan membuat serta mendesain kegiatan pembelajaran seperti: membuat silabus, RPKH, RPKM, serta membuat Alat Permainan Edukatif (APE) sesuai dengan tema-tema yang diajarkan pada semester I dan Semester 2 jika tidak tersedia di sekolah Taman Kanak-Kanak dan PAUD tersebut, sehingga peserta didik bermain sesukanya, tidak bisa mengenal huru abjad, tidak bisa mengenal huruf Hijaiyyah kalau pembelajaran agama Islam, tidak tahu alat permainan edukatif jenis apa saja yang dipelajari di Taman Kanak-Kanak Ini, tidak mengetahui tema-tema yang diajarkan seperti: tema diri sendiri, tema lingkunganku, tema kebutuhanku, tema Binatang, dan tanaman, kalau pada semester I, sedangkan pada semester II, tidak mengetahui tema-tema yakni: tema pekerjaanku, tema Tanah airku, tema Udara, air dan api, tema alam semesta, tema alat komunikasi, dan tema rekreasi.

Menurut hemat penulis, penilitian perihal eksistensi guru non-linier dalan melaksanakan desain pembelajaran di PAUD/TK masih belum banyak dilakukan secara akademis. Beberapa penelitian sebelumnya cenderung meneliti hal yang berkaitan dengan aspek perilaku anak didik terutama dari sisi perkembangan sosial-emosional, perkembangan kognitif anak PAUD/TK, dan lain sebagainya. Oleh karena itu, penelitiam ini penting untuk dilakukan sebagai indikator evaluatif untuk menilai kemampuan akademis para guru non-linier dalam desain pembelajaran di PAUD/TK khususnya di Kota Bima.

Berdasarkan uraian di atas, penulis berupaya untuk melakukan penelitian yang berkaitan dengan "Analisis Kemampuan Desain Pembelajaran Guru Non-Linier di PAUD/TK Se-Kota Bima”.

Jurnal Pelangi Jurnal pemikiran dan penelitian pendidkan Islam anak Usia Dini 


\section{METODE PENELITIAN}

Metodologi penelitian merupakan usaha seseorang yang dilakukan secara sistematis dengan mengikuti aturan-aturan penelitian guna menjawab permasalahan yang hendak diteliti. ${ }^{7}$ Jenis penelitian ini adalah kualitatif dengan jenis field research, yaitu peneliti mengadakan penelitian langsung terhadap objek yang diteliti dan dilakukan pengumpulan data yang ditemukan di lapangan. Penelitian ini termasuk jenis penelitian kualitatif, yaitu penelitian yang bermaksud untuk memahami fenomena tentang apa yang dialami oleh subjek penelitian misalnya perilaku, persepsi, motivasi, tindakan, dll.Secara holistik, dan dengancara deskripsi dalam bentuk kata-kata dan bahasa, pada suatu konteks khusus yang alamiah dan dengan memanfaatkan berbagai metode alamiah. Dalam penelitian ini penulis mengumpulkan data yang berhubungan dengan analisis kemampuan desain pembelajaran guru non linier di PAUD/TK Se-Kota Bima. ${ }^{8}$ Dan kegiatan dilaksanakan mulai tanggal 11 Juni s/d 31 Agustus 2019, di PAUD/TK Se-Kota Bima. ( TK Aisiyah I, Aisiyah II, dan Aisiyah III). Adapun subyek penelitianya adalah guru-guru PAUD/TK.

Analisis data yang dilakukan adalah suatu proses pengklasifikasian, pengkategorian, penyusunan, dan elaborasi, sehingga data yang telah terkumpul dapat diberikan makna untuk menjawab masalah penelitian. yang telah dirumuskan atau untuk mencapai tujuan penelitian. ${ }^{9}$ Berdasarkan jenis penelitian yang bersifat kualitatif, maka analisa data berlangsung pada saat pengumpulan data. Proses analisis mengalir dari tahap awal hingga tahap penarikan kesimpulan hasil studi. ${ }^{10}$

${ }^{7}$ Agus Salim, Teori dan Paradigma Penelitian Sosial, (Yogyakarta: Tiara Wacana, 2006), 22.

${ }^{8}$ Syahirman Yusi \& Umiyati Idris, Metodelogi Penelitian Ilmu Sosial Pendekatan Kuantitatif, (Palembang: Citra Books Indonesia, 2009), 103.

${ }^{9}$ Suharsimi Arikunto, Prosedur Penelitian Suatu Pendekatan Praktek, (Jakarta: Rineka Cipta, 1997), .34.

10 Sugiyono, Metode Penelitian Pendidikan, (Bandung: Alfabeta, 2011), 338. 


\section{HASIL PENELITIAN}

\section{Kemampuan Desain Pembelajaran Guru Non-Linier di PAUD/TK Se- Kota Bima}

Proses pembelajaranmenjadi titiktumpudalam pendidikan.Sehingga untuk mencapai tujuan pendidikan maka perlu desain pembelajaran yang bagus. Terutama guru sebagai ujung tombak pendidikan yang berhadapan dengan peserta didik dalam pembelajaran. ${ }^{11}$ Dalam mengajar seorang guru harus menghargai proses, tidak semata-mata hasilnya yang dilihat. Sering kali guru menilai dan menghargai murid dari hasil kerja saja. Sementara proses yang dijalani peserta didik selama menjalani proses belajarnya jarang diapresiasi. Faktanya keberhasilan di dalam kelas sangatlah dipengaruhi bagaimana kemampuan guru untuk mampu mengalihkan situasi dari yang membosankan, menjenuhkan dan tegang menjadi suasana aman dan nyaman, bersemangat dan merasa senang mendengarkan orang yang sedang berbicara di depan. ${ }^{12}$ Karena dengan pengalaman baik dan menyenangkan dalam belajar akan berdampak positif bagi perkembangan dan pertumbuhan si anak didik. Untuk mendukung itu semua diperlukan guru yang kreatif. Berdasarkan hasil wawancara dengan guru Taman Kanak-Kanak Aisyiyah I Kota Bima ibu Ida Hartini, S.Pd.I, menyatakan bahwa:

“Kami sebagai guru dalam mengajarkan kepada peserta didik tentu tidak semudah yang di bayangkan. Butuh lama untuk bisa membuat peserta didik nyaman. Dalam hal ini harus butuh kesabaran dalam mengajar peserta didik. Dalam mendesain pembelajaran supaya berjalan dengan baik dan menyenangkan maka dengan cara yang pertama, semua berawal dari menciptakan suasana pembelajaran (learning conditioning), artinya langkah paling awal untuk menciptakan suatu pembelajaran yang efektif adalah dengan menciptakan suasana pembelajaran yang kondusif dan nyaman bagi peserta didik maupun guru. Contohnya seperti pengkondisian ruang belajar, ruang belajar bisa dianalogikan sebagai sebuah kolam. Jika kolam itu kotor dan tidak ada sirkulasi udara yang baik maka ikan bakalan tidak nyaman bahkan

${ }^{11}$ https://Badarus, Desain Pembelajaran AUD, diakses pada tanggal 14 November 2019, Jam 09.38 Wita.

${ }^{12}$ Rusman, Model-Model Pembelajaran, Mengembangkan Profesionalisme Guru, (Bandung: Rajawali Pers, cet ke-2), 16.

Jurnal Pelangi Jurnal pemikiran dan penelitian pendidkan Islam anak Usia Dini 
mati.. Begitu juga dengan ruang belajar, jika ruangan tidak kondusif, maka kegiatan belajar yang efektif tidak akan terwujud. Kemudian yang kedua, pastikan ruang kelas (ruang pembelajaran) dalam kondisi bersih dan rapi sehingga konsentrasi pembelajaran tidak pecah hanya karena adanya kotoran atau barang berserakan yang mengganggu pemandangan." 13

Guru sebagai pendidik pada jenjang satuan pendidikan Anak Usia Dini, pendidikan dasar dan menengah memiliki peran yang sangat penting dalam menentukan keberhasilan peserta didik sehingga menjadi cerminan peningkatan kualitas pendidikan di sekolah. Pentingnya peran guru dalam pendidikan diamanatkan dalam Undang-Undang Republik Indonesia Nomor 20 Tahun 2003 tentang Sistem Pendidikan Nasional pada Pasal 3 yang berbunyi: "Pendidikan nasional berfungsi mengembangkan kemampuan dan membentuk watak serta peradaban bangsa yang bermartabat dalam rangka mencerdaskan kehidupan bangsa, bertujuan untuk berkembangnya potensi peserta didik agar menjadi manusia yang beriman dan bertakwa kepada Tuhan Yang Maha Esa, berakhlak mulia, sehat, berilmu, cakap, kreatif, mandiri, dan menjadi warga negara yang demokratis serta bertanggung jawab." ${ }^{14}$ UndangUndang Republik Indonesia Nomor 14 Tahun 2005 tentang Guru dan Dosen mengamanatkan adanya pembinaan dan pengembangan profesi guru sebagai aktualisasi dari profesi pendidik. Sudah sangat jelas fungsi guru dalam mengembangkan kemampuan peserta didik dalam meningkatkan kualitas Pendidikan di Indonsia. ${ }^{15}$

Kesiapan guru untuk mengajar berkaitan erat dengan cara guru mempersiapkan peserta didik untuk belajar. Kesiapan mengajar ini seperti petani mempersiapkan tanah untuk ditanami benih, jika dilakukan dengan benar, niscaya menciptakan kondisi yang baik untuk pertumbuhan yang sehat. Demikian juga dalam mengajar, jika persiapan yang lengkap sesuai dengan karakteristik kebutuhan, materi, metode, pendekatan, lingkungan serta kemampuan guru, maka hasinya diasumsikan akan lebih optimal.

${ }^{13}$ Hasil wawancara dengan Bu Ida Hartini pada Tanggal 5 Juni Tahun 2019 jam 10.12 Wita.

${ }^{14}$ Umar, Pengantar Profesi Keguruan ( Jakarta: PT. Rajawali Pers, 2019), 174.

${ }^{15}$ Yoki Ariyana, dkk,. Buku Pegangan Pembelajaran Berorientasi Pada Keterampilan Tingkat Tinggi Program Peningkatan Kompetensi Pembelajaran Berbasis Zonasi, (Direktoral Jenderal Guru dan Tenaga Kependidikan Kementerian Pendididikan dan Budaya), 1. 
Oleh sebab itu, guru yang baik untuk saat ini tidak cukup untuk sekedar bersikap hangat dan menyayangi peserta didik atau sekadar menerapkan praktik-praktik mengajar yang semata-mata didasarkan pada intuisi, preferensi pribadi atau kearifan konvensional. Tetapi lebih jauh untuk professional yang dimulai dengan kesiapan perencanaan sampai pada tahap evaluasi dengan berbagai kemampuan yang berhubungan dengan dunia pendidikan dan pengajaran.

Pendesainan program pengajaran dilakukan oleh guru dengan membuat perangkat pembelajaran, yaitu Protap (Program Tahunan), Promes (Program Semester), Modul, RPKH, RPKM, dan silabus, Protap adalah program pengajaran satu tahun, yang berisi inti dari program pembelajaran yang kemudian dijabarkan dalam promes. Hal ini berdasarkan hasil wawancara dengan ibu Rukayah selaku kepala sekolah dan juga guru di Taman Kanak-Kanak Aisyiyah III Kota Bima sebagai berikut:

"Program tahunan merupakan program umum setiap tema untuk setiap kelompok yakni kelompok A dan B, yang dikembangkan oleh guru kelompok A yang bersangkutan sebagai pedoman bagi pengembangan program-program selanjutnya, seperti RPKH dan RPKM pada setiap tema-tema yang diajarkan dalam setiap hari yang diajarkan dalam kegiatan kKegiatan Belajar Mengajar (KBM.) $)^{16}$

Adapun kemampuan dasar profesionalisme guru dalam mendesain pembelajaran secara rinci dapat dijabarkan sebagai berikut:

Merumuskan tujuan instruksional seperti; mengkaji kurikulum berdasarkan tema-tema pada Kelompok A dan Kelompok B, mempelajari ciri-ciri rumusan tujuan dari enam aspek yakni: 1) Nilai Agama dan Moraal, 2) Kognitif, 3) Motorik, 4) Sosial emosional, 5) Bahasa, dan 6) Seni.

Mengenal dan dapat menggunakan metode mengajar seperti; mempelajari macam-macam metode mengajar, menggunakan macammacam metode mengajar.

Memilih dan menyusun prosedur instruksional yang tepat seperti; mempelajari kriteria pemilihan tema dan prosedur mengajar, menggunakan kriteria pemilihan materi dan prosedur mengajar, merencanakan program pelajaran, dan menyusun satuan pelajaran. ${ }^{17}$

\footnotetext{
${ }^{16}$ Hasil wawancara dengan Bu Rukayah pada Tanggal 7 Juni Tahun 2019 Jam 10.30 Wita.

${ }^{17}$ Adis Chinta, Makalah Tentang Pengaruh Kemampuan Mengajar Guru, diakses pada tanggal 10 September 2019, Jam 13.20 Wita.
}

Jurnal Pelang̉i Jurnal pemikiran dan penelitian pendidkan Islam anak Usia Dini 


\section{Faktor-Faktor yang Menghambat Guru Non-Linier Dalam Melakukan Desain Pembelajaran di PAUD/TK Se-Kota Bima}

Menjadi seorang guru tidaklah mudah. Pun dengan segala predikat yang disandangnya yakni pahlawan tanpa tanda jasa, pekerjaan yang mulia, dan berbagai predikat terpandang lainnya tak membuang profesi ini kesepian dari suara-suara sumbang masyarakat. Suara-suara yang muncul tatkala pendidikan tak mampu lagi mencetak pribadi yang berkualitas dan berakhlak karimah. Memang tak mudah menjadi seorang guru yang profesional. Ada banyak hal tantangan dan segudang permasalahan yang harus diselesaikan agar menjadi seorang guru yang unggul dalam profesinya dan dapat mencetak pribadi yang berkualitas baik dari segi intelektual maupun dari segi religius. Dalam proses pembelajaran misalnya, banyak hal yang harus dipertimbangkan oleh seorang guru agar terciptanya situasi pembelajaran yang efektif.

Biasanya dalam pembelajaran guru menyajikan informasi kepada peserta didik dengan menggunakan berbagai metode, strategi, yang sesuai dengan standar kurikulum dan kemampuan peserta didik. Selain itu juga terjadi interaksi antara guru dengan peserta didik melalui tanya jawab, diskusi, kelompok kecil, serta pemberian tugas yang harus diselesaikan oleh peserta didik. Untuk menunjang keprofesionalitasnya seorang guru harus memiliki kemampuan untuk merencanakan program pembelajaran. Kemampuan untuk melaksanakan pembelajaran itu meliputi perencanaan pengorganisasian bahan pengajaran sampai dengan evaluasi pembelajaran dan penilaian hasil belajar.

Pelaksanaan pembelajaran sering mengalami kendala seperti terjadinya perubahan kurikulum, perubahan ini sengaja diciptakan oleh atasan yakni Depdiknas sebagai usaha untuk meningkatkan mutu pendidikan atau pemerataan kesempatan untukmemperoleh pendidikan, ataupun sebagai usaha untuk meningkatkan efisiensi dan sebagainya. Kendala-kendala lain juga yang mempengaruhi proses pembelajaran di dalam kelas seperti; (1) Perkiraan yang tidak tepat terhadap inovasi (2) Konflik dan motivasi yang kurang sehat (3) lemahnya berbagai faktor penunjang sehingga mengakibatkan tidak berkembangnya inovasi yang dihasilkan (4) Finansial yang tidak terpenuhi (5) Penolakan dari sekelompok tertentu atas hasil inovasi, serta (6) Kurang adanya hubungan 
sosial dan publikasi. ${ }^{18}$

Dalam pelaksanaan pengelolaan kelas akan ditemui berbagai faktor penghambat. Hambatan tersebut bisa datang dari guru sendiri, dan juga dari peserta didik, lingkungan keluarga ataupun karena faktor fasilitas. Hal ini diungkapkan oleh guru Taman Kanak-Kanak Aisyiyah I Kota Bima ibu Rahmawati sebagai berikut:

"Ada beberapa faktor yang menghambat guru dalam mendesain pembelajaran didalam kelas seperti; Guru sebagai seorang pendidik, tentunya ia juga mempunyai banyak kekurangan. Kekurangankekurangan itu bisa menjadi penyebab terhambatnya kreativitas pada diri guru tersebut. Kemudian yang kedua adalah tipe kepemimpinan guru (dalam mengelola proses belajar mengajar) yang otoriter dan kurang demokratis akan menimbulkan sikap pasif peserta didik. Sikap peserta didik ini akan merupakan sumber masalah pengelolaan kelas. Peserta didik hanya duduk rapi mendengarkan, dan berusaha memahami kaidah-kaidah pelajaran yang diberikan guru tanpa diberikan kesempatan untuk berinisiatif dan mengembangkan kreatifitas dan daya nalarnya." 19

Senada juga dengan apa yang sampaikan oleh "Bu Nurhasanah terkadang ada memang guru yang ketika mengajarnya hanya terlihat monoton saja. Gaya guru yang monoton akan menimbulkan kebosanan bagi peserta didik, baik berupa ucapan ketika menerangkan pelajaran ataupun tindakan. Ucapan guru dapat mempengaruhi motivasi peserta didik. Misalnya setiap guru menggunakan metode ceramah dalam mengajarnya, suaranya terdengar datar, lemah, dan tidak diiringi dengan gerak motorik/mimik. Hal inilah yang dapat mengakibatkan kebosanan belajar. Beliau juga menjelaskan tentang fasilitas pendukung dalam proses pembelajaran di dalam kelas. Fasilitas yang ada merupakan faktor penting upaya guru memaksimalkan programnya, fasilitas yang kurang lengkap akan menjadi kendala yang berarti bagi seorang guru dalam beraktivitas." 20

Menurut Syafruddin Nurdin ada beberapa pola kegiatan guru dalam pembelajaran serta tantangan yang dihadapinya antara lain: ${ }^{21}$

\footnotetext{
${ }^{18}$ Hasil wawancara dengan Bu Rohanai pada tanggal 6 Juni Tahun 2019 Jam 10.15 Wita.

${ }^{19}$ Hasil wawancara dengan Bu Rahmawati pada tanggal 6 Juni Tahun 2019 Jam 10.25 Wita.

${ }^{20}$ Ibid.. 12

${ }^{21}$ Ruhimat, dkk, "Kurikulum \& Pembelajaran" Jurusan Kurtekpend, Fakultas Ilmu
}

Jurnal Pelangi Jurnal pemikiran dan penelitian pendidkan Islam anak Usia Dini 


\section{Pola pembelajaran yang efektif}

Guru sebagai tenaga pendidik harus mampu mensinergiskan suatu kegiatan pembelajaran dengan metode pembelajaran yang digunakannya. Hal ini dapat menunjang kemampuan peserta didik dalam berorientasi mengolah tema-tema yang akan diajarkan. Tantangan yang acap kali dihadapi adalah guru sering tidak mampu menganalisa gaya dan pola belajar peserta didik, sehingga hal ini memungkinkan pemakaian metode pembelajaran yang salah dan tidak sesuai dengan kepribadian peserta didik. Sebagai contoh banyak peserta didik dapat belajar mandiri, sementara peserta didik lainnya lebih senang belajar dalam situasi pengajaran yang beraturan dan terpimpin. Perbedaan diantara peserta didik ini mengharuskan guru menggunakan berbagai metode pengajaran yang berbeda pula.

\section{Kondisi dan Asas untuk Belajar yang Berhasil}

Pengajaran yang efektif ditandai oleh berlangsungnya proses belajar secara optimal. Proses belajar dapat dikatakan berlangsung apabila peserta didik dapat mengetahui atau melakukan sesuatu yang sebelumnya tidak diketahui atau dapat dilakukan olehnya. Jadi hasil belajar akan terlihat dengan adanya tingkah laku baru dalam pengetahuan berpikir atau kemampuan jasmaniah. Dikarenakan tugas perancangan pengajaran adalah membantu terjadinya proses belajar, maka seorang guru harus mampu menyadari dan memanfaatkan kondisi dan asas yang telah terbukti mendukung proses belajar tersebut dengan baik. ${ }^{22}$

Agus Makmun Dan Abdul Mukti mengemukakan, ada dua macam klasifikasi tantangan yang dihadapi oleh pendidik dewasa ini, yang mana tantangan tersebut bersifat internal dan eksternal. Adapun tantangan yang bersifat internal menyangkut program pemahaman, perencanaan, pelaksanaan, penerapan, dan evaluasi. Sedangkan tantangan eksternal menyangkut kemajuan IPTEK, globalisasi informasi, perubahan politik, sosial, dan budaya bangsa. ${ }^{23}$

\footnotetext{
Pendidikan, Universitas Pendidikan Indonesia, 2009, 19.

${ }^{22}$ Zainal Masri, Makalah Tentang, Tantangan Guru Dalam Pembelajaran, diakses pada tanggal 20 September 2019, Jam 12.30 Wita.

${ }^{23}$ Arif Rahman, Makalah Tentang, Hambatan dalam Perencanaan dan Pelaksanaan Pembelajaran
} 
Problematika inilah yang dihadapi oleh setiap tenaga pendidik dalam pembelajaran disekolah. Peserta didik yang mengidap penyakit moral pun menjadi perhatian utama oleh guru, dimana gejala awal seperti tidak mau belajar, apatis terhadap keadaan buruk yang menimpanya, pergaulan yang menohok perilaku sosialnya, dan penyakit-penyakit sosiallainnya akan sulit oleh guru untuk mengubah perilakunya. Disinilah dibutuhkan sosok seorang guru yang sempurna dimana ia mampu untuk "meng-install" kembali perilaku mental dan sosial peserta didik. Tenaga kependidikan itu harus mampu mengkombinasikan sentuhansentuhan akal, emosional, dan spiritual yang bergerak disemua aspek perilaku peserta didik.

\section{Upaya Guru Non-Linier Dalam Meningkatkan Kemampuan Desain Pembelajara di PAUD/TK Se-Kota Bima}

Peningkatan mutu pendidikan merupakan salah satu program pemerintah yang dilaksanakan dengan berbagai macam. Dalam meningkatkan mutu pendidikan tersebut khususnya perbaikan kurikulum, pelatihan guru, penyediaan sarana dan prasarana pendidikan yakni sarana bermain bagi anak PAUD/TK. Pentingnya pendidikan Taman Kanak-Kanak karena melalui usaha ini dapat membantu anak didik dalam mengembangkan potensi, minat, keterampilan, kemampuan pada dirinya sebagai modal dasar agar siap memasuki pendidikan selanjutnya. Dalam rangka meningkatkan kemampuan dalam mendesain pembelajaran peran pendidik sangat diperlukan sebagai upaya meningkatkan proses pembelajaran PAUD/TK dengan melaksanakan berbagai macam pengajaran yang salah satunya adalah membuat pembelajaran menarik, sehingga proses pembelajaran berjalan dengan baik.

Peningkatan pengetahuan dan keterampilan guru PAUD/TK ini akan berpengaruh terhadap kemampuan guru PAUD/TK dalam melaksanakan proses pembelajaran di Taman Kanak-kKanak sehingga pencapaian tujuan pembelajaran di Taman Kanak-Kanak yaitu untuk meletakan dasar-dasar pengembangan kemampuan fisik, bahasa, sosial

diakses pada tanggal 30 September 2019, Jam 13.00 Wita.

Jurnal Pelang̉i Jurnal pemikiran dan penelitian pendidkan Islam anak Usia Dini 
emosional, konsep diri, seni dan nilai-nilai agama sehingga upaya pengembangan anak tercapai secara optimal atau disebut dengan enam aspek yaitu 1) Nilai Agama dan Moraal, 2) Kognitif, 3) Motorik, 4) Sosial emosional, 5) Bahasa, dan 6) Seni.

Perencanaan pembelajaran merupakan langkah yang sangat penting sebelum pelaksanaan pembelajaran. Perencanaan yang matang diperlukan supaya pelaksanaan pembelajaran berjalan secara efektif. Perencanaan pembelajaran dituangkan ke dalam Rencana Kegiatan Pembelajaran Harian (RPKH) atau beberapa istilah lain seperti desain pembelajaran, skenario pembelajaran. RPKH memuat enam aspek yaitu 1) Nilai Agama dan Moraal, 2) Kognitif, 3) Motorik, 4) Sosial emosional, 5) Bahasa, dan 6) Seni, tema-tema yang akan dipelajari, metode pembelajaran, langkah pembelajaran, media pembelajaran, dan sumber belajar atau APE (Alat Permainan Edukatif) serta penilaian.

Guru harus mampu berperan sebagai perencanaan (planning), Pengorganisasian (organizing), pelaksanaan (actuating), penilaian (evaluator) kegiatan pembelajaran. Guru merupakan faktor yang paling penting karena di tangan gurulah keberhasilan pembelajaran dapat dicapai. Kualitas mengajar guru secara langsung maupun tidak langsung dapat mempengaruhi kualitas pembelajaran pada umumnya. Seorang guru dikatakan profesional apabila; (1) Serius melaksanakan tugas profesinya, (2) Bangga dengan tugas profesinya, (3) Selalu menjaga dan berupaya meningkatkan kompetensinya, (4) Bekerja dengan sungguh tanpa harus diawasi, (5) Menjaga nama baik profesinya, (6) Bersyukur atas imbalan yang diperoleh dari profesinya. ${ }^{24}$

Salah satu solusinya adalah dengan mengikuti pendidikan dan pelatihan guru. ${ }^{25}$ Usaha lain yang dapat dilakukan oleh guru dalam mendesain proses pembelajaran di dalam yaitu:

Penguasaan bahan (Tema-Tema), yang meliputi: menguasai dan mengkaji kurikulum pendidikan GTK PAUD dan Dikmas serta menguasai bahan pengajaran, mengkaji kurikulum dan menelaah APE (Alat Permainan Edukatif) menelaan dan berlatih melaksanakan

${ }^{24}$ Rahmah, Skripsi tentang, Upaya Meningkatkan Kompetensi Guru Dalam Menyusun Rencana Pelaksanaan Pembelajaran Melalui Bimbingan Berkelanjutan di SMP Tegalsari II Kabupaten Majalengka Tahun 2010, 6.

${ }^{25}$ Hasil wawancara dengan Bu Hafsah pada tanggal 8 Juni Tahun 2019 Jam 10.35 Wita. 
kegiatan-kegiatan yang dinyatakan dalam buku teks pedoman GTK PAUD dan Dikmas mengkaji bahan penunjang yang relevan dengan bahan APE (Alat Permainan Edukatif) dan yang relevan dengan profesi guru. ${ }^{26}$

Mengelola program belajar-mengajar. Dalam mengelola program belajar-mengajar ini guru dapat berusaha dengan cara: menyusun program pengajaran dengan cara mengkaji ciri-ciri tujuan pengajaran dan berlatih merumuskan serta menetapkan tujuan, berlatih memilih dan mengembangkan tujuan yang akan dicapai dengan mengembangkan bahan sesuai dengan tujuan, memilih dan berlatih mengkaji, mengembangkan strategi belajar-mengajar dengan penggunaan metode, media dan memanfaatkan sumber belajar atau APE (Alat Permainan Edukatif). ${ }^{27}$

Mengelola kelas. Usaha yang dapat dilakukan oleh guru dalam mengelola kelas antara lain: mengatur ruangan belajar dengan berlatih dan mengkaji data ruang belajar-mengajar, penggunaan serta berusaha menata ruangan yang rapi agar peserta didik senang dan kerasan menggunakannya, menciptakan iklim belajar yang tepat dengan cara mengkaji prinsip-prinsip pengelolaan kelas, faktor-faktor yang mempengaruhi, menciptakan suasana belajar serta berlatih menangani masalah pengajaran dan pengelolaan.

Menggunakan media/sumber belajar yakni APE (Alat Permainan Edukatif), yang meliputi: mengkaji berbagai media pengajaran yang sesuai dengan bahan yang disajikan, berlatih memilih membuat dan menggunakan media pengajaran.

Menguasai landasan pendidikan, yang melipputi: mengenal dan mengkaji tujuan pendidikan dasar untuk mencapai tujuan pendidikan nasional, mengkaji kegiatan-kegiatan pengajaran yang menunjang pencapaian tujuan pendidikan nasional. ${ }^{28}$

Pelaksanaan pembelajaran sangat ditentukan keberhasilannya oleh keterampilan guru dalam mendesain pembelajaran. Tenaga pengajar

${ }^{26}$ Mulyasa, Menjadi Kepala Sekolah Profesional dalam Konteks Menyukseskan MBS dan KBK, ( Bandung: Remaja Rosdakarya, 2004), 111

${ }^{27}$ Cece Wijaya, Kemampuan Dasar Guru dalam Proses Belajar-Mengajar, ( Bandung: Remaja Rosdakarya, 2005), 25.

${ }^{28}$ Nana Sudjana, Cara Belajar Siswa Aktif dalam Proses Belajar Mengajar, ( Bandung: Sinar Dunia, 2008), 37.

Jurnal Pelang̉i Jurnal pemikiran dan penelitian pendidkan Islam anak Usia Dini 
yang kompentesial dan professional, akan terukur dari sejauh mana dia dapat mendesain pembelajaran dan mengajarkannya dalam sebuah proses pembelajaran di kelas, sehingga dapat mengantarkan peserta didiknya mencapai hasil belajar yang optimal. ${ }^{29}$

Keberhasilan belajar sangat ditentukan oleh tenaga pengajarnya, hal ini disebabkan, tenaga pengajar selain sebagai perencana (plainning) dan orang yang berperan dalam proses transformasi pengetahuan dan keterampilan, juga dia memandu segenap proses pembelajaran. Di tangannyalah, sebuah peristiwa belajar dapat berlangsung. Padanya pula, pembelajaran akan diserahkan dan kemana peserta didik akan dibawa.

Guru sebagai pekerja profesional harus memiliki keterampilan desain pembelajaran, selain itu harus memfasilitasi dirinya dengan seperangkat pengalaman, keterampilan dan pengetahuan tentang keguruan sesuai keilmuan yang ditekuninya. Banyak guru dalam belajar, masih terkesan hanya gugur kewajiban. Guru semacam ini, relatif tidak memerlukan suatu desain yang baik, strategi, kiat dan berbagai metode tertentu di dalam mengajar.

\section{KESIMPULAN}

Berdasarkan hasil temuan dilapangan tentang Analisis Kemampuan Desain Pembelajaran Guru Non-Linier di PAUD/TK Se-Kota Bima. Keberhasilan belajar sangat ditentukan oleh tenaga pengajarnya, hal ini disebabkan, tenaga pengajar selain sebagai perencanaan (planning) dan orang yang berperan dalam proses transformasi pengetahuan dan keterampilan, juga dia memandu segenap proses pembelajaran. Di tangannyalah, sebuah peristiwa belajar dapat berlangsung. Padanya pula, pembelajaran akan diserahkan dan kemana peserta didik akan dibawa.

Guru tidak hanya sebagai pengajar saja, akan tetapi bagaimana cara seorang guru dalam mendesain pembelajaran yang menyenangkan dalam kelas maupun di luar kelas, sehingga proses pembelajaran akan terlihat baik serta nyaman dan berjalan dengan lancar. Selain mendesain

\footnotetext{
${ }^{29}$ Yendra Patrial. Makalah Tentang Merancang Media Pembelajaran, diakses pada tanggal 12 September 2019, Jam 10.35 Wita.
} 
pembelajaran guru juga perlu membentuk berkepribadian anak seperti sifat jujur, disiplin, tanggung jawab, toleransi, gotong royong, santun, percaya diri, wibawa, dan lain-lain.

\section{REFERENSI}

Agus Salim, Teori dan Paradigma Penelitian Sosial, (Yogyakarta: Tiara Wacana, 2006),

Arif Rahman, Makalah Tentang, Hambatan dalam Perencanaan dan

Pelaksanaan Pembelajaran diakses pada tanggal 30 September 2019, Jam 13.00 Wita.

Adis Chinta, Makalah Tentang Pengaruh Kemampuan Mengajar Guru, diakses pada tanggal 10 September 2019, Jam 13.20 Wita.

Cece Wijaya, Kemampuan Dasar Guru dalam Proses Belajar-Mengajar, (Bandung: Remaja Rosdakarya, 2005),

Mulyasa, Menjadi Kepala Sekolah Profesional dalam Konteks Menyukseskan MBS dan KBK, ( Bandung: Remaja Rosdakarya, 2004),

Nana Sudjana, Cara Belajar Siswa Aktif dalam Proses Belajar Mengajar, ( Bandung: Sinar Dunia, 2008),

Roby Maulana Putra, Hubungan antara Kemampuan Mengajar Guru TIK Non-Liner dengan Hasil Belajar Siswa pada Mata Pelajaran Teknologi Informasi dan Komunikasi (TIK),

Rusman, Model-Model Pembelajaran, Mengembangkan Profesionalisme Guru, (Bandung: Rajawali Pers, cet ke-2)

Ruhimat, dkk, "Kurikulum \& Pembelajaran" Jurusan Kurtekpend, Fakultas Ilmu Pendidikan, Universitas Pendidikan Indonesia, 2009

Rahmah, Skripsi tentang, Upaya Meningkatkan Kompetensi Guru Dalam Menyusun Rencana Pelaksanaan Pembelajaran Melalui Bimbingan Berkelanjutan di SMP Tegalsari II Kabupaten Majalengka Tahun 2010,

Sulis Triyono, dkk., Tentang Penguatan Kompetensi Pedagogik Mahasiswa Jurusan Pendidikan Bahasa Jerman FBS Universitas Negeri Yogyakarta, Syahirman Yusi \& Umiyati Idris, Metodelogi Penelitian Ilmu Sosial Pendekatan Kuantitatif, (Palembang: Citra Books Indonesia, 2009) Suharsimi Arikunto, Prosedur Penelitian Suatu Pendekatan Praktek, (Jakarta: Rineka Cipta, 1997)

Jurnal Pelang̉i Jurnal pemikiran dan penelitian pendidkan Islam anak Usia Dini 
Sugiyono, Metode Penelitian Pendidikan, (Bandung: Alfabeta, 2011) Undang-Undang Nomor 14 tahun 2005 Tentang Guru Dan Dosen, 56 Umar, Pengantar Profesi Keguruan, (Jakarta: PT. Rajagrafindo Persada: Cetakan ke-1 januari 2019)

Umar, Pengantar Profesi Keguruan ( Jakarta: PT. Rajawali Pers, 2019)

Yoki Ariyana, dkk,. Buku Pegangan Pembelajaran Berorientasi Pada Keterampilan Tingkat Tinggi Program Peningkatan Kompetensi Pembelajaran Berbasis Zonasi, ( Direktoral Jenderal Guru dan Tenaga Kependidikan Kementerian Pendididikan dan Budaya)

Yendra Patrial. Makalah Tentang Merancang Media Pembelajaran, diakses pada tanggal 12 September 2019, Jam 10.35 Wita.

Zainal Masri, Makalah Tentang, Tantangan Guru Dalam Pembelajaran, diakses pada tanggal 20 September 2019, Jam 12.30 Wita.

https://Badarus, Desain Pembelajaran AUD, diakses pada tanggal 14 November 2019, Jam 09.38 Wita.

Hasil wawancara dengan Bu Ida Hartini pada Tanggal 5 Juni Tahun 2019 jam 10.12 Wita.

Hasil wawancara dengan Bu Rukayah pada Tanggal 7 Juni Tahun 2019 Jam 10.30 Wita.

Hasil wawancara dengan Bu Rohanai pada tanggal 6 Juni Tahun 2019 Jam 10.15 Wita.

Hasil wawancara dengan Bu Rahmawati pada tanggal 6 Juni Tahun 2019 Jam 10.25 Wita.

Hasil wawancara dengan Bu Hafsah pada tanggal 8 Juni Tahun 2019 Jam 10.35 Wita. 